\title{
Analysis of Productivity Differences among Foreign and Domestic firms: Evidence from Germany ${ }^{1}$
}

\author{
Yama Temouri, Nigel L. Driffield, and Dolores Añón Higón \\ Aston University, Birmingham
}

\begin{abstract}
This paper presents differences in firm-level total factor productivity (TFP) across 22 manufacturing and 17 service industries in Germany over the period 19952004. It is an attempt to study whether and to what extent foreign multinational enterprises (MNEs) are more productive relative to German firms. As well as distinguishing between foreign and domestic firms, we also distinguish between German MNEs and domestic firms that do not have any foreign presence. Controlling for endogeneity through semi-parametric techniques, our findings indicate considerable heterogeneity in firm performance across types of firms. The foreign/domestic distinction is not as clear cut as has been suggested elsewhere; multinationality is important in explaining productivity differences rather than foreignness.
\end{abstract}

JEL no. D24, F21, F23

Keywords: Multinationals; productivity; Germa

\footnotetext{
${ }^{1}$ Published in 2008, The Review of World Economics, 144(1), 32-54. I am grateful to John Sutton, Dennis Mueller, Sourafel Girma, Davide Castellani, Christian Bellak and participants at the AIB conference in Manchester, $5^{\text {th }}$ Postgraduate Conference in Nottingham, $9^{\text {th }}$ INFER workshop in Leuven, EUNIP conference in Limerick and EARIE conference in Amsterdam for helpful comments and suggestions.
} 


\section{Introduction}

Much of the theoretical literature on multinational enterprises (MNEs) starts with the presumption that FDI is motivated by the desire to exploit some form of firm-specific advantage in another country (Dunning, 1988). When examining firms in a given location, this advantage then leads to foreign investors being on average more productive than domestic firms. Indeed, this presumption is the basis for the literature concerning the potential spillover effects of inward investment in a given location (for reviews see Blomström et al., 2001; Görg and Greenaway, 2004). However, the limited evidence that exists for Germany suggests that this productivity differential is not clear cut; Bellak and Pfaffermayr (2002) for example argue that some results suggest that domestically-owned firms can indeed outperform foreign-owned firms, contrary to expectations. Generally however, such findings vary with the performance measure used and the level of technology employed in the firms concerned. Subsidiaries with low-skill, labour intensive assembly line operations may be less productive than their domestic counterparts which may use superior technology in the same industry.

Most work in this area focuses on the comparison between foreign and domestic firms in a given location. Much of this is based on the UK (Davies and Lyons, 1991; Oulton, 1998a, b; Griffith, 1999), the United States (Howenstine and Zeile, 1992; Doms and Jensen, 1998) and Canada (Globerman et al., 1994). There is surprisingly little work on this for Germany, arguably the most technologically advanced country in Europe, which attracts in excess of 10 per cent of inward investment into the EU. 
This chapter offers two contributions. First, it presents a detailed and systematic analysis of productivity differences at the firm-level in German manufacturing and service industries for the various regions of Germany over 10 years. Second, it highlights the differences in performance across foreign subsidiaries of different nationalities, and domestic MNEs on the one hand and domestic non-MNEs ${ }^{2}$ on the other hand. Much of the analysis in this area hitherto has ignored the distinction between purely domestic firms, and home country multinationals, which to quote Doms and Jensen (1998) is equivalent to “comparing apples and oranges”.

Germany offers an interesting contrast to many recipients of inward investment, in that it has high levels of indigenous technological development, mainly in the Western states, but at the same time still relatively underdeveloped Eastern states. This has been the situation since unification, despite 18 years of enormous financial transfers from the federal government to the Eastern states. The attempt to modernize the backward state of the Eastern regions and narrowing the gap in living standards between East and West Germany has taken much longer than anticipated (Sinn, 2002). As it was only after unification in 1990 that the former East Germany opened up to foreign investments, one would expect significant differences in firm-level productivity across German regions and types of firms.

The rest of this chapter is organized as follows. Section 2 gives an overview of previous empirical studies of productivity differences, with a particular focus on Germany. Section 3 describes our data set and offers some descriptive statistics.

\footnotetext{
${ }^{2}$ These are firms with only domestic operations which may or may not export.
} 
Section 4 discusses the econometric approach and the methodology involved. Section 5 presents the results and section 6 concludes and offers some future lines of research.

\section{Previous Empirical Evidence}

As the economic rationale for the special treatment of foreign-owned firms, policymakers cite positive externalities generated by FDI through productivity spillovers from foreign to domestic firms (Department of Trade and Industry, 2006). This in fact will only occur if MNEs are superior to domestic firms in their technological capability or productivity performance. This technological advantage of foreign investors over domestic firms has in recent years become a stylised fact in the applied and policy-oriented literature concerned with FDI flows or the impacts of inward investment. Indeed, many empirical studies have found MNEs to be more productive.

Davies and Lyons (1991) measure the extent to which foreign firms operating in the UK have an aggregate productivity advantage ${ }^{3}$ over domestic firms in UK manufacturing industries over the period 1971-1987. Recognising that data for aggregate manufacturing fail to control for the possibility that foreign firms may be attracted to more productive industries and are disproportionately represented in such industries (structural effect), they develop a two-tier decomposition method to distinguish between the structural and ownership effect at the 2-digit and 3-digit industry level. They find that foreign firms are on average 48.6 per cent more productive, which is 23.5 per cent due to the ownership effect and 20.3 per cent due to the structural effect. Davies and Lyons (1991) among others cast doubt on the

\footnotetext{
${ }^{3}$ They define productivity as gross value added per person employed.
} 
reliability of the cross-sectional evidence of previous studies due to an endogeneity bias. It is argued, that much of the superior performance of MNEs is likely made up of compositional effects and omitted variables (Conyon et al., 2004).

Oulton (1998a, 1998b) are among the first studies to examine productivity differences at a more disaggregated level, using both plant and firm-level data from the Annual Respondents Database (ARD) dataset for UK manufacturing and the OneSource ${ }^{4}$ data set for the UK services sector. For UK manufacturing Oulton (1998a) estimates labour productivity (value added per worker) to be 38 per cent higher for foreign subsidiaries relative to domestic firms. For UK service industries Oulton (1998b) finds a foreign productivity advantage of one-third compared with domestic firms. In both of these studies, the variation in performance is due to foreign firms using high physical and human capital-intensive factors of production.

Griffith (1999) using the ARD establishment level data set analyses TFP differences in the UK motor vehicle industry over the period 1980-1992. This industry is chosen by Griffith because it has the highest proportion of foreign ownership among all other UK industries. The findings of Griffith (1999) demonstrate a significant TFP advantage for German and US subsidiaries over UK domestic firms. Griffith and Simpson (2004) extend this analysis by taking into account all UK manufacturing industries over the period 1980 to 1996 . Again, their methodology is along standard lines of estimating Cobb Douglas production functions using dummies for various firm nationalities and controlling for age, size of establishment and probability of exit

\footnotetext{
${ }^{4}$ The OneSource database is commercially available, and like Amadeus based on company account data. It is however limited to larger firms than the threshold for Amadeus, and limited to the UK. The ARD covers the UK manufacturing sector, and services since 1997, at the establishment level. This however does not include financial information, or details of ownership structures. See Griffith (1999) and Oulton (1998b) for detailed description of the ARD and OneSource, respectively.
} 
and time effects. Their findings suggest that establishments under foreign ownership have higher labour productivity than under domestic ownership.

A significant shortcoming of these and related studies ${ }^{5}$ which compare foreign firms with all domestic plants is that they may seriously be affected by a "selection problem" because the group of domestic firms is heterogeneous (Criscuolo and Martin, 2005). Domestic plants include non-MNEs as well as MNEs which can rival foreign-owned firms in terms of productivity levels. Thus, the superior productivity performance of foreign firms may not be a foreign ownership advantage per se, but may simply reflect a MNE advantage. Studies incorporating this aspect are Doms and Jensen (1998) for the US, Criscuolo and Martin (2005) for the UK, Bellak and Pfaffermayr (2002) for Austria, Bellmann and Jungnickel (2002) for Germany. These studies essentially find that foreign subsidiaries have higher productivity than domestic non-MNEs while foreign and domestic MNEs differ only marginally, whereby U.S. subsidiaries are the most productive.

Recent work by Arnold and Hussinger (2006) tests the prediction by Helpman et al. (2004) that the most productive firms in an economy are those that invest abroad. They present total factor productivity differences among a subset of German firms for the period 1996 to 2002. However their data does not include foreign-owned firms. Nevertheless, they are able to divide German firms into non-exporting domestic firms which they find to be least productive, followed by domestic exporting firms, while firms which undertake FDI are the most productive. Wagner (2006) also shows

\footnotetext{
${ }^{5}$ See, e.g. Howenstine and Zeile (1992), Globerman et al. (1994), Braconier and Ekholm (2002) and Bellak and Pfaffermayr (2002).
} 
evidence supporting the Helpman et al. (2004) hypothesis for a sample of manufacturing firms ${ }^{6}$ operating in the German state of Lower Saxony.

Bellmann and Jungnickel (2002) show that foreign-owned firms are more productive than German non-MNEs as well as German MNEs. As the authors acknowledge however, their data has several limitations, namely relying on turnover rather than value added to capture productivity, and having limited data on multinationality ${ }^{7}$.

Peri and Urban (2006) test whether foreign-owned and West German firms induce technological spillovers in favour of domestic firms in the Eastern regions of Germany. They find foreign-owned and West German firms to be more productive than East German firms and show evidence for a positive technological catch-up process of local East German firms through productivity spillovers. However, the focus in Peri and Urban (2006) is the spillover process and thus they do not analyse productivity differences in any great detail. For example, they do not test for differences in Western regions, but more importantly they do not distinguish by type of domestic firm.

Most of the studies mentioned above concentrate on the manufacturing sector, either on aggregate or at the firm-level, which is certainly due to the fact that micro-data for the service sector is not readily available for many countries. Another difficulty is finding appropriate deflators for monetary variables in this sector. The present paper incorporates the services sector in the analysis in addition to the manufacturing sector.

\footnotetext{
${ }^{6}$ Information on these firms was collected in personal interviews. However, using a partial productivity measure (value-added per employee) on a cross-section in the year 1995 is a disadvantage, as acknowledged by the author.

${ }^{7}$ German MNEs are proxied by an export quota of at least 30 per cent.
} 
This is important because the services sector is a knowledge-intensive sector which plays an ever more important role in advanced economies attracting large amounts of foreign investment. Also, it is of high significance from a policy perspective to know performance differences in order to identify the industries which are promising in terms of spillovers (we will return to this point in the conclusion).

\section{Data Sources and Descriptive Statistics}

Our data is taken from Amadeus $^{8}$, a rich firm-level dataset, provided by Bureau van Dijk, which is an electronic publishing and consultancy firm. A growing number of researchers have used this data set in recent years to analyse various economic issues, including Helpman et al. (2004), Budd et al. (2005) and Konings and Murphy (2006). It offers detailed financial and other operational information on private and public companies operating in Western as well as Eastern European countries. The dataset used in this paper comes from the intermediate version ${ }^{9}$ of Amadeus.

Detailed information about ownership structure is given for every year of the sample period. This is an advantage to previous studies which assume (using the same data set) that the ownership information for the latest year of their sample period is valid for the entire period (e.g. Konings and Murphy, 2006; Peri and Urban, 2006).

\footnotetext{
${ }^{8}$ Analyse Major Databases from EUropean Sources. Bureau van Dijk compiles public and private company accounts from so called regional information providers (IPs) which are either Central Banks, Official statistical offices or a credit rating agency. The data for Germany are retrieved by Bureau van Dijk from annual company accounts published by Creditreform, Germany's largest credit rating agency.

${ }_{9}^{9}$ The three versions are the top 250,000 companies in Europe, the top 1.5 million and all companies which amount to approximately 9 million firms (including small firms). Using the intermediate version of Amadeus, the selection of firms is based on satisfying at least one of the following criteria: number of employees equal to at least 20, total operating revenues and total assets equaling to at least $€ 1.5$ million and $€ 3$ million, respectively. This of course includes the coverage of purely domestic firms which on average are smaller (see table 3); though for the comparison of large to medium sized inward investors with domestic counterparts this presents no obvious problems.
} 
Although the actual timing of the investment decision is not given in the data set, we can in effect trace changes in ownership for most firms and determine the amount and the source country of the foreign capital throughout the panel period using earlier Amadeus releases retrieved from historical discs.

Another unique feature of the data set is the identification of foreign-owned firms as well as domestic MNEs, an issue which is rarely addressed in the literature. For each firm, data on the country of the holding company which owns the company in question and the country of the ultimate holding company is given. Either or both of these may of course be missing, in which case we assume that it is a German-owned firm.

A foreign firm is defined as one in which at least 10 per cent of equity is owned by a foreign business entity. This threshold is suggested and used for statistical purposes by the $\mathrm{IMF}^{10}$, UNCTAD (2005), OECD ${ }^{11}$; many OECD countries, including Germany $^{12}$ and is common in the literature (e.g. see Griffith et al. 2004; and Doms and Jensen, 1998). The threshold of $10 \%$ is considered to represent a meaningful stake and effective voice in the management of the firm. The nationality of a firm is determined by the ultimate parent's country of ownership ${ }^{13}$. All firms not meeting this criterion are defined as German owned including firms without ownership information, which is common practice for the database (Peri and Urban, 2006) ${ }^{14}$.

\footnotetext{
${ }^{10}$ See Balance of Payments Manual (IMF, 1993).

${ }^{11}$ See Benchmark Definition of Foreign Direct Investment (OECD, 1996).

12 See Deutsche Bundesbank's Zahlungsbilanzstatistik September 2006, pp.48-9 or International Capital Links April 2006 pp.19-20.

${ }^{13}$ If the ultimate owner is not known, the country of ownership is identified using the nationality of the immediate owner. This is a reasonable assumption as the percentage ownership is directly used in the analysis. We have experimented with various specifications which do not change the results.

${ }^{14}$ There are gaps in reports when the data is not made available by the firms either in accordance with the national laws or in violation with the national laws. Germany, according to BvD, is a special case as
} 
Subsidiary information, i.e. either name or operating revenue of the subsidiary, is taken as evidence that a German firm is a MNE.

Due to variation in national reporting requirements, a significant number of firms have limited financial information; missing observations for variables considered in this analysis or are simply inactive. We simply include company information on the basis of data availability and exclude outliers ${ }^{15}$. Table 1 shows the distribution of firms by firm-type for the year $2002^{16}$. Firms are classified according to the NACE industry classification at the 2-digit level. For a detailed list of NACE codes and industries see Appendix 5A.

Table 1 Distribution of Manufacturing Firms and Service Firms (2002)

\begin{tabular}{lcc}
\hline \hline & Manufacturing & Services \\
\hline Non-MNE $^{\mathrm{D}}$ & 2,672 & 5,928 \\
MNE $^{\mathrm{D}}$ & 326 & 366
\end{tabular}

accounts are only made available for around 15,000 firms (which include many small companies). Other German firms, mainly private firms, do not file their accounts and are thus not included even though they would meet the selection criteria.

${ }^{15}$ To exclude possible outliers we excluded from the sample the top and bottom one percentile of all the firm-specific output and input variables. We also dropped unusual changes in observations which seemed to be "key punch errors" such as negative values for intermediate inputs, capital and where intermediate inputs were greater than output.

${ }^{16}$ We choose to show the distribution of firms for the year 2002 for two reasons. Firstly, most firms are observed in year 2002 which due to the unbalanced nature of our panel means that not all firms are observed throughout the panel period. But more importantly, the distribution of firms across regions, industries and ownership status does not change significantly in either the manufacturing or the service sector over time. Thus, choosing a representative year suffices for illustrative purposes. 
Note: $\mathrm{MNE}^{\mathrm{D}}$ and $\mathrm{MNE}^{\mathrm{F}}$ represent domestic and foreign multinationals, respectively. Non$\mathrm{MNE}^{\mathrm{D}}$ stands for German non-multinational firms. In each year, a foreign firm is defined as one in which at least 10 per cent is owned by a foreign business entity. All firms not meeting this criterion are defined as German owned.

Source: Authors' calculations from Amadeus data set.

Table 2 reports some descriptive statistics on the key variables employed. They reveal that German MNEs are on average larger, more capital intensive and have higher sales figures than foreign-owned firms followed by domestic non-MNEs.

Table 2 Descriptive Statistics

\begin{tabular}{|c|c|c|c|}
\hline & \multicolumn{3}{|c|}{ Mean (Standard deviation) } \\
\hline & $\mathrm{MNE}^{\mathrm{F}}$ & $\mathrm{MNE}^{\mathrm{D}}$ & Non-MNE $^{\mathrm{D}}$ \\
\hline Sales & $\begin{array}{c}251,720 \\
(492,192)\end{array}$ & $\begin{array}{c}420,962 \\
(666,545) \\
\end{array}$ & $\begin{array}{c}106,222 \\
(296,944)\end{array}$ \\
\hline Capital $^{\mathrm{a}}$ & $\begin{array}{c}100,543 \\
(262,592) \\
\end{array}$ & $\begin{array}{c}197,571 \\
(365,910) \\
\end{array}$ & $\begin{array}{c}74,240 \\
(205,536) \\
\end{array}$ \\
\hline $\begin{array}{l}\text { No of } \\
\text { Employees }\end{array}$ & $\begin{array}{c}1,273 \\
(2,460) \\
\end{array}$ & $\begin{array}{c}2,404 \\
(3,768) \\
\end{array}$ & $\begin{array}{c}788 \\
(1,928) \\
\end{array}$ \\
\hline $\begin{array}{l}\text { Material } \\
\text { Costs }\end{array}$ & $\begin{array}{c}178,104 \\
(341,586) \\
\end{array}$ & $\begin{array}{c}265,351 \\
(426,011) \\
\end{array}$ & $\begin{array}{c}72,794 \\
(213,325) \\
\end{array}$ \\
\hline
\end{tabular}

${ }^{a}$ Capital is measured as the book value of the firm's fixed assets.

Note: Figures are calculated over the period 1995-2004. All monetary values are deflated and expressed in thousands of US\$.

Source: Authors' calculations from Amadeus data set.

An overview of the regional and sectoral distribution of all manufacturing and service firms is presented in Tables 3 and 4 . Around 85 per cent of all foreign manufacturing subsidiaries and 94 per cent of all foreign services subsidiaries are located in the Western states. The Eastern states are host to a minority which is not very surprising considering the still relative underdeveloped regions of the East and the many 
important determinants which foreign investors consider prior to investing. The sectoral composition shows substantial differences in foreign presence, from low levels of a few per cent to around 75 per cent in some industries.

Table 3 Regional breakdown (2002)

\begin{tabular}{|c|c|c|c|c|c|c|}
\hline & \multicolumn{3}{|c|}{ Manufacturing } & \multicolumn{3}{|c|}{ Services } \\
\hline & $\begin{array}{l}\text { Non- } \\
\text { MNE }^{\mathrm{D}}\end{array}$ & $\mathrm{MNE}^{\mathrm{D}}$ & $\mathrm{MNE}^{\mathrm{F}}$ & $\begin{array}{l}\text { Non- } \\
\text { MNE }^{\mathrm{D}}\end{array}$ & $\mathrm{MNE}^{\mathrm{D}}$ & $\mathrm{MNE}^{\mathrm{F}}$ \\
\hline Baden-Württemberg & 353 & 62 & 46 & 611 & 59 & 92 \\
\hline Bayern & 422 & 63 & 83 & 1,070 & 78 & 154 \\
\hline Berlin & 41 & 15 & 8 & 269 & 19 & 22 \\
\hline Bremen & 9 & 1 & 3 & 42 & 6 & 2 \\
\hline Hamburg & 27 & 13 & 6 & 141 & 16 & 42 \\
\hline Hessen & 184 & 23 & 34 & 492 & 43 & 100 \\
\hline Niedersachsen & 246 & 28 & 27 & 524 & 17 & 27 \\
\hline Nordrhein-Westfalen & 599 & 90 & 86 & 1,166 & 97 & 171 \\
\hline Rheinland-Pfalz & 77 & 12 & 8 & 135 & 8 & 11 \\
\hline Saarland & 33 & 7 & 2 & 57 & 3 & 5 \\
\hline Schleswig-Holstein & 48 & 8 & 8 & 124 & 8 & 11 \\
\hline Brandenburg* & 96 & 1 & 3 & 216 & 1 & 5 \\
\hline Mecklenburg-Vorp.* & 85 & 1 & 8 & 313 & 3 & 11 \\
\hline Sachsen* & 250 & 5 & 24 & 532 & 7 & 15 \\
\hline Sachsen-Anhalt* & 95 & 2 & 13 & 135 & 1 & 4 \\
\hline Thüringen* & 107 & 6 & 6 & 101 & 1 & 3 \\
\hline
\end{tabular}

Note: * denote states in Eastern Germany.

Source: Authors' calculations from Amadeus data set.

Table 4 Distribution of firms across industries, 2002

\begin{tabular}{lcccc}
\hline $\begin{array}{l}\text { NACE } \\
\text { classification }\end{array}$ & $\begin{array}{c}\text { Non- } \\
\text { MNE }\end{array}$ & MNE $^{\mathrm{D}}$ & MNE $^{\mathrm{F}}$ & $\begin{array}{l}\text { Foreign employment by } \\
\text { industry }\end{array}$ \\
\hline \multicolumn{5}{c}{ (per cent) }
\end{tabular}




\begin{tabular}{|c|c|c|c|c|}
\hline 20 & 71 & 4 & 11 & 43.11 \\
\hline 21 & 42 & 10 & 12 & 8.13 \\
\hline 22 & 107 & 6 & 12 & 46.33 \\
\hline 23 & 11 & 0 & 2 & 10.01 \\
\hline 25 & 99 & 21 & 16 & 14.45 \\
\hline 26 & 95 & 14 & 12 & 28.04 \\
\hline 27 & 87 & 17 & 16 & 27.44 \\
\hline 28 & 348 & 19 & 28 & 19.35 \\
\hline 36 & 68 & 10 & 13 & 7.11 \\
\hline 37 & 26 & 2 & 0 & 0.00 \\
\hline \multicolumn{5}{|c|}{ Manufacturing: High-technology } \\
\hline 24 & 135 & 32 & 43 & 21.21 \\
\hline 29 & 306 & 69 & 48 & 19.18 \\
\hline 31 & 114 & 16 & 24 & 30.15 \\
\hline 34 & 60 & 17 & 11 & 16.41 \\
\hline 35 & 48 & 4 & 8 & 33.32 \\
\hline 30 & 35 & 3 & 7 & 19.33 \\
\hline 32 & 53 & 13 & 23 & 15.41 \\
\hline 33 & 111 & 19 & 30 & 20.16 \\
\hline \multicolumn{5}{|c|}{ Services: Low-technology } \\
\hline 45 & 936 & 19 & 33 & 17.18 \\
\hline 50 & 312 & 4 & 24 & 18.45 \\
\hline 51 & 1,209 & 89 & 258 & 18.32 \\
\hline 52 & 440 & 13 & 40 & 18.00 \\
\hline 55 & 48 & 2 & 7 & 27.49 \\
\hline 60 & 242 & 7 & 4 & 5.08 \\
\hline 63 & 231 & 9 & 23 & 3.47 \\
\hline \multicolumn{5}{|c|}{ Services: High-technology } \\
\hline 61 & 18 & 2 & 5 & 75.11 \\
\hline 62 & 7 & 1 & 0 & 0.00 \\
\hline 64 & 23 & 1 & 1 & 5.03 \\
\hline 65 & 38 & 2 & 5 & 48.26 \\
\hline 67 & 25 & 2 & 3 & 10.33 \\
\hline 70 & 881 & 11 & 21 & 5.29 \\
\hline 71 & 74 & 5 & 6 & 2.12 \\
\hline 72 & 291 & 27 & 47 & 16.32 \\
\hline 73 & 58 & 4 & 11 & 52.22 \\
\hline 74 & 1,095 & 168 & 187 & 16.49 \\
\hline
\end{tabular}

${ }^{a}$ Per cent share of that industry's employment accounted for by foreign affiliates.

Note: Industry Classification according to OECD-EUROSTAT (Laafia, 2002); also see Appendix 5B. Classification for services available at http://europa.eu.int/estatref/info/sdds/en/htec/htec_sectors.pdf

Source: Authors' calculations from Amadeus data set.

\section{Econometric Approach and Estimation Issues}

The approach and methodology taken in this paper follows along fairly standard lines

which are well developed and adopted in previous studies (see e.g., Griffith, 1999).

The main form of analysis will focus on production functions, as discussed in chapter

2, from which TFP levels are estimated in an attempt to identify potential productivity 
differences. The standard measurement technique describes the process in terms of a production function augmented by measures on foreign presence along industry and regional lines. This essentially involves estimating the following basic model:

$$
\begin{aligned}
& y_{i t}=\alpha_{k} k_{i t}-\alpha_{l} l_{i t}-\alpha_{m} m_{i t}+\varepsilon_{i t} \\
& \hat{\varepsilon}_{i t}=\rho M N E_{i}^{F}+\pi \operatorname{Dom}_{i}^{\text {West }}+\eta \operatorname{Dom}_{i}^{\text {East }}+\beta_{j}+\beta_{t}+\beta_{r}+v_{i t}
\end{aligned}
$$

where subscripts $i, t, j, r$ refer to firm, year, industry and region respectively; $y_{i t}, k_{i t}, l_{i t}$, and $m_{i t}$ represent the log of a firm's output (sales) and the production inputs: capital (measured as the book value of fixed assets), labour ${ }^{17}$ (number of employees) and material costs respectively. In equation (1) $\varepsilon_{i t}$ represents the TFP residual while in equation (2) the $v_{i t}$ represents the error term. To deflate monetary values we use the appropriate producer price index for each manufacturing industry and consumer price index for services. All price indices are taken from the German Federal Statistical Office. The dummy $M N E^{F}$ represents foreign subsidiaries. $D o m_{i}{ }^{\text {aast }}$ and $D_{0 m}{ }^{\text {West }}$ refer to dummies for East German non-MNEs and West German non-MNEs, respectively.

In terms of estimation, the first step essentially includes obtaining an estimate of TFP from (1), as the residual of the production function. The second step involves decomposing the TFP estimate into its determinants using (2). This paper divides foreign firms into three foreign ownership groups which are thought to exhibit variations in performance in accordance with previous studies (Criscuolo and Martin, 2005): (a) firms owned by the United States, (b) firms owned by the member

\footnotetext{
${ }^{17}$ There is no breakdown by type of labour or by skill but we can calculate the average wage which may serve as a proxy for the average level of human capital per worker.
} 
countries of the European Union (excluding the ten new members) and (c) countries of the rest of the world (RoW) which mainly includes other OECD countries ${ }^{18}$.

Further, we analyse productivity differences between subgroups of domestic firms, namely German MNEs, German non-MNEs located in the Western states and their counterpart in the East states, whereby the German MNEs acts as the reference group in the regressions. We further extend the analysis by allowing for differences, not only across industries, but also by testing whether ownership effects differ across industries with different levels of technological sophistication. Firms are grouped in line with Eurostat/OECD classification into Low and High technology-intensive sectors for manufacturing and the service sector (see Appendix 5B for classification). We control for both firm size and age. Firm age is measured in years and defined in 3 age classes ${ }^{19}$ : 1 to 10 years, 11 to 30 years and 31 years or older. Firm size is measured by the number of employees. Using a classification scheme common in German official statistics, we define the following size classes: 1-20 employees, 21 to 49 employees, 50 to 99 employees, 100 to 249 employees, 250 to 499 employees, and 500 employees or more.

There are a number of econometric problems associated with estimating unobserved productivity as the residual of the production function, even with firm-level data on the capital, labour and material inputs. The most common problem concerns endogeneity. The endogeneity problem occurs when at least a part of the TFP is unobserved by the econometrician but observed by the firm at a time early enough so as to allow the firm to change the factor input decision. If that is the case, then profit

\footnotetext{
${ }^{18}$ For example, a firm is classified as US-owned if either the country of the holding company or of the ultimate holding company is the US. If this is missing, the country of the holding company will be assumed to be Germany. Other foreign ownership countries are determined in a similar manner.

${ }^{19} \mathrm{~A}$ firm's age is defined from the date of incorporation to the current financial year.
} 
maximization implies that the realisation of the error term is expected to influence the decision on factor inputs. In other words, the regressors and the error term are correlated, which makes OLS estimation biased and inconsistent.

The remedies to control for endogeneity include, among others, the Olley and Pakes (1996) approach (OP) which uses investment as an indicator or proxy for productivity shocks. However, one of the limitations of the OP approach is that it requires firms to make positive investments every year, which may not necessarily be present in actual firm-level data sets due to substantial adjustment costs following productivity shocks. This would cause the loss of a large number of observations. Levinsohn and Petrin (2003) (LP) extend the OP approach by using material inputs as a proxy to control for unobservable productivity shocks, as it is more common for firms to register material costs every year. In other words, since a firms' intermediate input typically responds more smoothly to productivity shocks than capital investment, the strict monotonicity assumption is more likely to hold. This makes material costs a better proxy to use in the inversion of the unobserved part of the production function (i.e. the intermediate demand function) $)^{20}$.

This paper uses the latter approach to address the endogeneity problem. The advantage of this approach over more traditional estimation techniques is its ability to more effectively control for the correlation between unobservable productivity shocks and inputs. The argument is that in the presence of adjustment costs, materials are likely to react more rapidly than investments to any productivity shocks.

\footnotetext{
${ }^{20}$ See Appendix 5C for a brief description of the LP technique.
} 
A recent critique by Ackerberg et al. (2005) highlights the restrictiveness of assuming that labor is perfectly flexible in the LP approach, which may lead to a potential identification problem of the variable input (labour). To overcome the potential collinearity problem, they propose an extension of LP approach, which involves estimating the labour coefficient in the second stage, in contrast to LP and OP. In this regard, Wooldridge (2005) proposes an alternative more efficient, one-step GMM estimation approach. Nevertheless the LP remains one of the most popular approaches in the literature (see for example Smarzynska Javorcik 2004; Griffith et al. 2006), as none of these extensions or alternatives has yet to emerge as superior in all cases. We would stress that the LP estimation technique is consistent with a range of realistic underlying assumptions about firm behaviour, and in particular allows us to correct for the endogeneity problem of capital, particularly important in the context of FDI.

\section{Results}

Table 1 reports the results of three specifications of (2) for the manufacturing sector in high and low-technology industries. Table 2 presents the same for the service sector. The three specifications estimated differ only in the way firms are classified so as to shed light on productivity differences. The first specification (A) groups all foreign firms together whereas specification (B) distinguishes between three nationalities of foreign MNEs. Specification (C) extends this by examining different levels of holdings, testing for differences between minority-owned (10-50\%) and majorityowned (51-100\%) foreign firms. The estimates of total factor productivity from (1) are derived using the Levinsohn and Petrin (2003) approach while (2) is estimated by OLS, with full sets of industry, region and time dummies ${ }^{21}$.

\footnotetext{
${ }^{21}$ We do not present fixed effects estimation because the unobservable fixed effect is collinear with various time-invariant variables.
} 
The coefficients on non-MNEs located in East and West Germany have the expected sign in that they are significantly different from zero and significantly different from each other across all specifications ${ }^{22}$. This is true for overall manufacturing, high-tech as well as low-tech manufacturing across all specifications. This seems to suggest that non-MNEs are less productive than German MNEs, namely 0.06-0.21 for Western non-MNEs and 0.21-0.41 for Eastern non-MNEs. Estimates for the foreign MNEs $\left(\mathrm{MNE}^{\mathrm{F}}\right)$ show a productivity advantage in overall and high-tech manufacturing of 0.08 and 0.24 , respectively, whereas in low-tech manufacturing a -0.10 disadvantage in productivity is shown.

${ }^{22}$ Coefficients on dummy variables are not strictly elasticities (Halvorsen and Palmquist 1980). However, in order to compare coefficients we have tested that coefficients are indeed significantly different from each other. 
Table 5 Manufacturing (dependent variable: $\log$ TFP; reference group: $\mathrm{MNE}^{\mathrm{D}}$ )

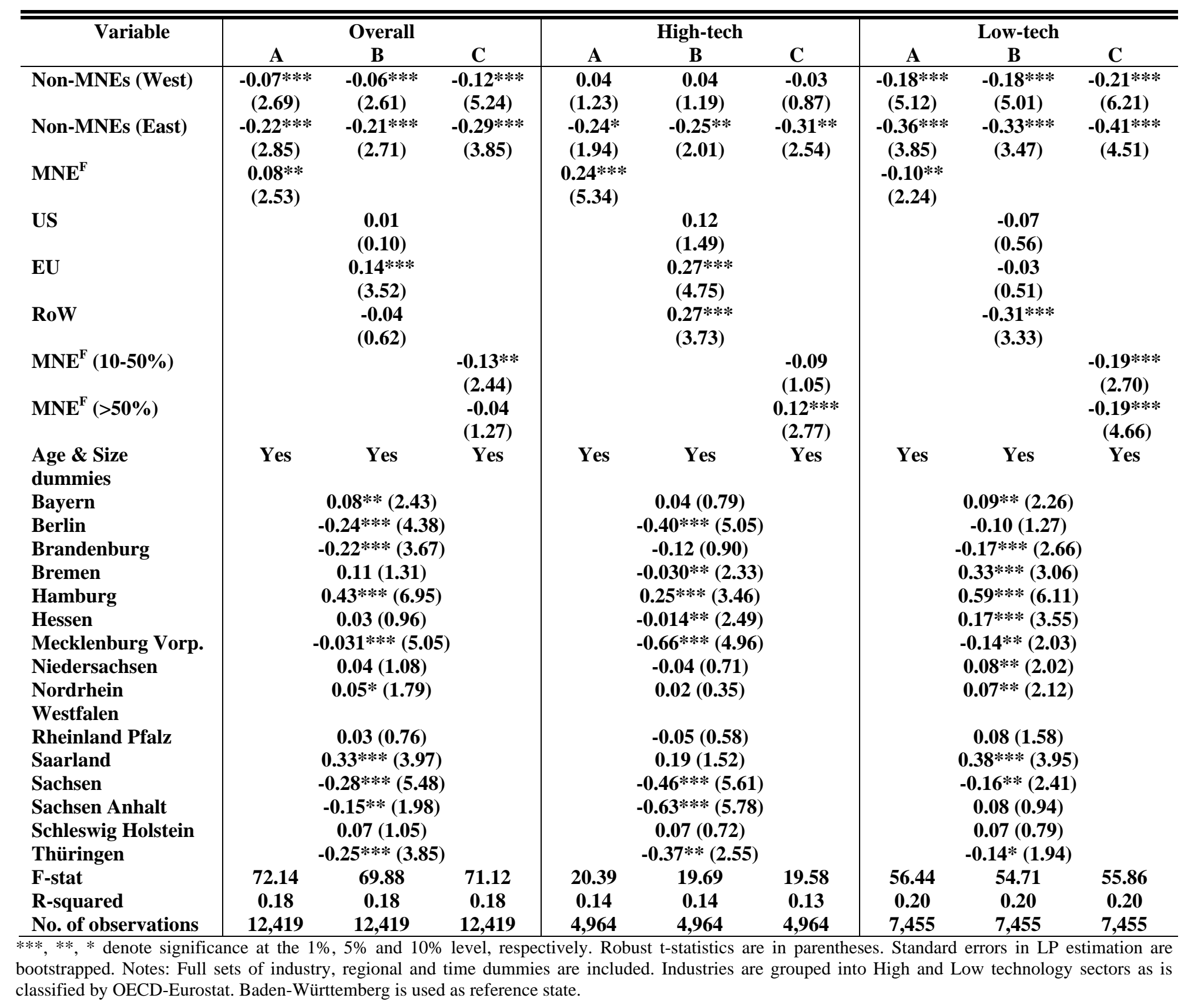


Specification (B) shows that firms owned by other OECD countries (i.e. RoW) are less productive in low-tech industries (-0.31) but more productive in high-tech industries (0.27). There is also evidence that EU firms are more productive in overall manufacturing and equally productive in high-tech industries as the RoW group (0.27). There is no evidence to suggest that US firms have any productivity advantage over German MNEs regardless of industry classification. Distinguishing between foreign-owned firms with minority and majority holdings demonstrates that minorityowned foreign firms tend to be less productive than majority-owned foreign firms. In high-tech industries majority-owned foreign firms show a significant positive difference of 0.12 whereas in low-tech industries both types of ownership show a 0.19 disadvantage in productivity vis-à-vis the reference group. Controlling for age and size reveals no discernable productivity advantage towards either older/younger or smaller/larger firms.

Table 6 shows results for the German service sector. Once more, non-MNEs exhibit negative and statistically significant coefficients for high and low-tech service industries, as well as for the full sample. The exception is non-MNEs in Eastern Germany in low-tech industries. Foreign MNEs grouped together show no significant difference in either high or low-tech service industries. EU-owned firms show a slight significance of 0.14 in low-tech industries but more interestingly US-owned firms reveal a 0.37 productivity disadvantage in low-tech industries vis-à-vis German MNEs. The differentiation between minority and majority-owned foreign firms shows that the former are less productive at around 0.20 across industries, whereas the latter show a 0.13 advantage in overall services but no difference in high or low-tech industries. Again, estimates for age and size classes reveal no discernable productivity advantage towards either older/younger or smaller/larger firms. 
Table 6 Services (dependent variable: $\log$ TFP; reference group: MNE ${ }^{\mathrm{D}}$ )

\begin{tabular}{|c|c|c|c|c|c|c|c|c|c|}
\hline \multirow[t]{2}{*}{ Variable } & \multicolumn{3}{|c|}{ Overall } & \multicolumn{3}{|c|}{ High-tech } & \multicolumn{3}{|c|}{ Low-tech } \\
\hline & A & B & C & A & B & C & A & B & C \\
\hline non-MNEs (West) & $\begin{array}{c}-0.07 * * * \\
(2.69)\end{array}$ & $\begin{array}{c}-0.06 * * * \\
(2.61)\end{array}$ & $\begin{array}{c}-0.29 * * * \\
(8.94)\end{array}$ & $\begin{array}{c}-0.16 * * * \\
(3.84)\end{array}$ & $\begin{array}{c}-0.16 * * * \\
(3.84)\end{array}$ & $\begin{array}{c}-0.16 * * * \\
(4.07)\end{array}$ & $\begin{array}{c}-0.42 * * * \\
(7.49)\end{array}$ & $\begin{array}{c}-0.42 * * * \\
(7.38)\end{array}$ & $\begin{array}{c}-0.43^{* * *} \\
(8.46)\end{array}$ \\
\hline non-MNEs (East) & $\begin{array}{c}-0.22 * * * \\
(2.85)\end{array}$ & $\begin{array}{c}-0.21 * * * \\
(2.71)\end{array}$ & $\begin{array}{c}-0.24^{*} \\
(1.82)\end{array}$ & $\begin{array}{c}-0.44^{* *} \\
(2.29)\end{array}$ & $\begin{array}{c}-0.46^{* *} \\
(2.35)\end{array}$ & $\begin{array}{c}-0.46^{* *} \\
(2.30)\end{array}$ & $\begin{array}{l}-0.08 \\
(0.58)\end{array}$ & $\begin{array}{l}-0.12 \\
(0.84)\end{array}$ & $\begin{array}{c}-0.11 \\
(0.75)\end{array}$ \\
\hline $\mathrm{MNE}^{\mathrm{F}}$ & $\begin{array}{c}\mathbf{0 . 0 8 * *} \\
(2.53)\end{array}$ & & & $\begin{array}{l}-0.03 \\
(0.47)\end{array}$ & & & $\begin{array}{c}0.05 \\
(0.81)\end{array}$ & & \\
\hline US & & $\begin{array}{c}0.01 \\
(0.10)\end{array}$ & & & $\begin{array}{l}-0.08 \\
(0.79)\end{array}$ & & & $\begin{array}{c}-0.37 * * * \\
(2.69)\end{array}$ & \\
\hline EU & & $\begin{array}{c}0.14 * * * \\
(3.52)\end{array}$ & & & $\begin{array}{l}-0.06 \\
(0.86)\end{array}$ & & & $\begin{array}{l}0.14^{*} \\
(1.80)\end{array}$ & \\
\hline RoW & & $\begin{array}{c}-0.04 \\
(0.62)\end{array}$ & & & $\begin{array}{c}0.10 \\
(0.86)\end{array}$ & & & $\begin{array}{c}0.06 \\
(0.70)\end{array}$ & \\
\hline $\operatorname{MNE}^{\mathrm{F}}(10-50 \%)$ & & & $\begin{array}{c}-0.21 * * * \\
(2.91)\end{array}$ & & & $\begin{array}{c}-0.23 * * * \\
(2.67)\end{array}$ & & & $\begin{array}{l}-0.18 * \\
(1.69)\end{array}$ \\
\hline $\operatorname{MNE}^{\mathrm{F}}(>50 \%)$ & & & $\begin{array}{c}0.13^{* * *} \\
(3.37)\end{array}$ & & & $\begin{array}{c}0.07 \\
(1.35)\end{array}$ & & & $\begin{array}{l}0.06 \\
(1.11)\end{array}$ \\
\hline $\begin{array}{l}\text { Age \& Size } \\
\text { dummies }\end{array}$ & Yes & Yes & Yes & Yes & Yes & Yes & Yes & Yes & Yes \\
\hline Bayern & & $0.12 * * *(3$. & & & $0.19 * * *(4$ & & & $0.02(0.31)$ & \\
\hline Berlin & & $0.32 * * *(6$. & & & $0.43 * * *(7$ & & & $-0.17 *(1.87)$ & \\
\hline Brandenburg & & $0.64 * * *(7$. & & & $-0.67 * * *(6$ & & & $-0.55^{* * *}(3.46)$ & \\
\hline Bremen & & $-0.09(1.33$ & & & $0.00(0.0$ & & & $-0.18 *(1.76)$ & \\
\hline Hamburg & & $0.17 * * *(2.8$ & & & $-0.18 * *(2$. & & & $0.57 * * *(6.30)$ & \\
\hline Hessen & & $-0.03(0.73$ & & & $-0.09 *(1$. & & & 0.11 (1.61) & \\
\hline Mecklenburg Vorp. & & $0.76^{* * *}(10$ & & & $0.71 * * *(7$ & & & $-0.76 * * *(6.58)$ & \\
\hline Niedersachsen & & $-0.09 * *(1 . \subseteq$ & & & $-0.08(1.4$ & & & $-0.07(0.87)$ & \\
\hline Nordrhein & & $-0.03(0.85$ & & & $0.24 * * *(5$ & & & $0.23^{* * *}(4.14)$ & \\
\hline Westfalen & & & & & & & & & \\
\hline Rheinland Pfalz & & $0.24 * * *(2$ & & & $-0.42 * * *(4$ & & & $-0.01(0.12)$ & \\
\hline Saarland & & $0.09(0.74$ & & & $0.07(0.4$ & & & $0.11(0.70)$ & \\
\hline Sachsen & & $0.76^{* * *}(14$ & & & $0.77 * * *(9$ & & & $-0.64 * * *(8.79)$ & \\
\hline Sachsen Anhalt & & $0.54 * * *(3$. & & & $0.67 * * *(3$ & & & $-0.38 *(1.77)$ & \\
\hline Schleswig Holstein & & $0.30 * * *(4$. & & & $-0.70 * * *(7$ & & & $0.06(0.74)$ & \\
\hline Thüringen & & $0.41 * * *(3$ & & & $-0.54 * * *(3$ & & & $-0.11(0.60)$ & \\
\hline F-stat & 96.64 & 96.64 & 96.64 & 60.67 & 58.01 & 59.55 & 76.19 & 73.24 & 74.34 \\
\hline R-squared & 0.29 & 0.29 & 0.29 & 0.31 & 0.31 & 0.31 & 0.31 & 0.31 & 0.31 \\
\hline No. of observations & 10,967 & 10,967 & 10,967 & 5,895 & 5,895 & 5,895 & 5,072 & 5,072 & 5,072 \\
\hline
\end{tabular}


It is important to note that these ownership differences would not have been uncovered, had we compared foreign firms with all domestic firms. To make the point, table 7 shows a comparison between foreign firms versus all domestic firms, as has been done in previous studies. Our results show that foreign firms are significantly more productive than all domestic firms grouped together acting as the reference group. However, the specifications (A) to (C) in the previous tables have shown that such a simple comparison leads to biased results.

Table 7 Simple comparison (dependent variable: log TFP ; reference group: domestic firms )

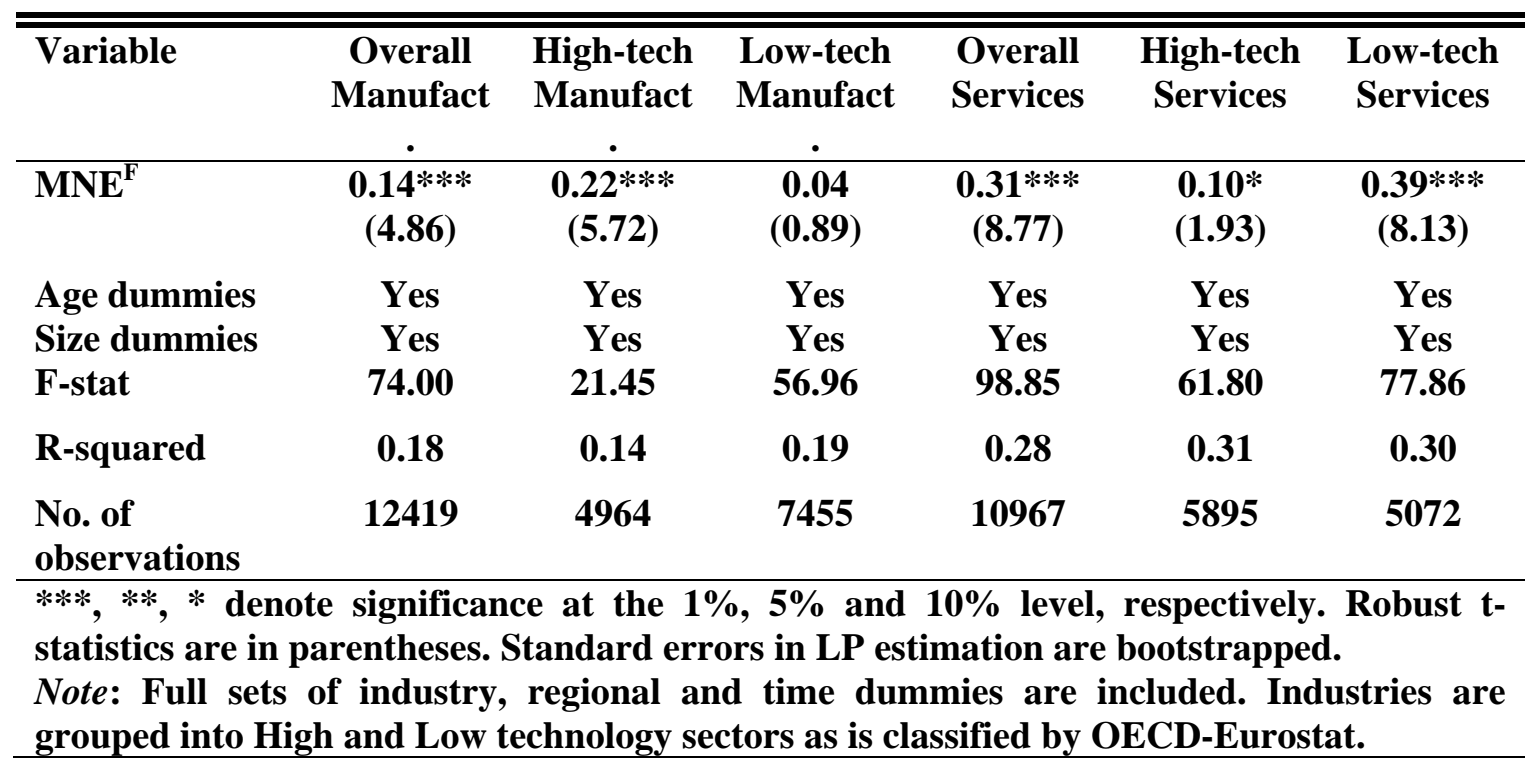

The productivity gap also holds if we distinguish between Eastern firms which are in turn owned by West German parents versus East German parents (see table A1 in the Appendix). Being located in the East but owned by a West German firm shows a statistically significant productivity advantage of between 0.13 and 0.22 compared with East German owned firms. As our results show a significant productivity gap exists between East and West German firms, and so the question of catch-up is inevitable. Although our paper does not set out to provide a comprehensive analysis of catch-up in the 
East, the results are nevertheless informative. In terms of productivity levels, Tables 5 and 6 illustrate that the Eastern state dummies (Brandenburg, Mecklenburg-Vorpommern, Sachsen, Sachsen-Anhalt, Thüringen) are mostly negative and significant along all specifications. However, with respect to the catching up issue, the table A2 in the Appendix shows average TFP growth figures for West and East for all industries in our analysis. While there exists significant heterogeneity in the total factor productivity growth across regions and industries, there is little evidence of catch up of the Eastern states.

\section{Conclusions}

This paper extends the existing literature on productivity differences between foreignowned firms and domestic firms. By presenting analysis of productivity (TFP) differences across three types of firms, operating in 22 manufacturing and 17 service industries in Germany we highlight considerable heterogeneity in firm performance. Estimating augmented production functions, this paper uses the semi-parametric approach proposed by Levinsohn and Petrin (2003) to address the endogeneity problem.

In general, while one can identify a “foreign” effect (foreign firms in Germany are in general more productive than domestic firms), to label this as "foreign ownership advantage” would be misleading. Rather, that while German non-MNEs are less productive than foreign-owned firms, there is no such difference between German MNEs and foreignowned subsidiaries. Equally, location within Germany is also important, as this productivity gap is more pronounced for firms which are located in the Eastern states. Furthermore, firms which are located in East Germany but in turn are owned by West German firms outperform firms with East German parents. 
These results have two important policy implications. Firstly, in common with most European countries, there has been increased focus recently in Germany on attracting inward investment (Federal Ministry of Economics and Technology 2007). However, it is doubtful whether such a policy will contribute to productivity growth in Germany overall, though inward investment may boost productivity growth in the East. The productivity advantage held by East German firms owned by a Western parent over an Eastern parent also suggests, in a similar vein to those reported by Castellani and Zanfei (2006) for Italy, that a focus on indigenous development may generate larger long term effects. However, there is so far little evidence of catch up of the Eastern states.

Secondly, there is a large and growing literature concerned with the potential spillover or externality effects of inward investment. This is largely concerned with testing for productivity growth in the domestic sector following inward investment, and is predicated on the assumption that inward investors have higher productivity than the domestic firms. Generally, spillovers are expected where there are significant differences in productivity between types of firms. The results presented here suggest that the potential of any spillover effects can have two sources, namely foreign MNEs as well as domestic MNEs. Although this paper does not test for spillovers directly, it gives an indication of where such spillovers are most likely to occur. Indeed, disentangling differences in productivity is an important first step prior to any attempt to test for productivity spillovers. More specifically, our results suggest that any spillover effects from FDI into Germany may be limited to certain regions of the country, especially the eastern regions.

Having investigated how differences in firm-level productivity relate to foreign and domestic ownership and multinationality, the focus of future research is to actually go 
ahead and test for spillovers. As Germany is arguably the most technologically advanced economy in Europe, we might find that the dominant model of FDI into Germany may not be one of technology exploitation, but of "technology sourcing”, in that foreign MNEs may seek to invest in Germany, not in order to exploit existing firm specific advantages, but to acquire them from local firms. The extent to which such phenomena are observed in Germany is an empirical question, highlighting the need for further research in this area, particularly in the German context, with particular reference to future initiatives that may link inward investment to economic and technological development. 


\section{Appendix}

Table A1: Eastern firms owned by West-German parents

Dependent Variable: $\log$ TFP

Reference Group: Eastern firm owned by East-German parent

\begin{tabular}{|c|c|c|c|c|c|c|}
\hline Variable & $\begin{array}{c}\text { Overall } \\
\text { Manufact. }\end{array}$ & $\begin{array}{l}\text { High-tech } \\
\text { Manufact. }\end{array}$ & $\begin{array}{l}\text { Low-tech } \\
\text { Manufact. }\end{array}$ & $\begin{array}{c}\text { Overall } \\
\text { Services }\end{array}$ & $\begin{array}{c}\text { High- } \\
\text { tech } \\
\text { Services }\end{array}$ & $\begin{array}{c}\text { Low-tech } \\
\text { Services }\end{array}$ \\
\hline $\begin{array}{l}\text { non-MNEs } \\
\text { (East) owned by } \\
\text { West German } \\
\text { parent }\end{array}$ & $\begin{array}{c}\mathbf{0 . 1 6}^{* * *} \\
(3.54)\end{array}$ & $\begin{array}{c}\mathbf{0 . 1 8}^{* * *} \\
(2.96)\end{array}$ & $\begin{array}{l}0.13^{* *} \\
(2.00)\end{array}$ & $\begin{array}{l}0.17 * \\
(1.85)\end{array}$ & $\begin{array}{c}0.17 \\
(\mathbf{0 . 9 0})\end{array}$ & $\begin{array}{l}0.22 * * \\
(2.13)\end{array}$ \\
\hline Age dummies & Yes & Yes & Yes & Yes & Yes & Yes \\
\hline Size dummies & Yes & Yes & Yes & Yes & Yes & Yes \\
\hline F-stat & 12.55 & 8.78 & 4.01 & 3.43 & 0.81 & 4.53 \\
\hline $\begin{array}{l}\text { No. of } \\
\text { observations }\end{array}$ & 1727 & 906 & 821 & 1016 & 436 & 580 \\
\hline
\end{tabular}


Table A2: Average TFP Growth (1995 to 2004)

\begin{tabular}{|c|c|c|c|}
\hline NACE & Industry & $\begin{array}{l}\text { West } \\
\text { Germany }\end{array}$ & $\begin{array}{l}\text { East } \\
\text { Germany }\end{array}$ \\
\hline 15 & Food products and beverages & $0.53(5.91)$ & $0.01(5.78)$ \\
\hline 17 & Manufacture of textiles & $0.19(5.88)$ & $0.01(4.91)$ \\
\hline 18 & Manufacture of wearing apparel; dressing and dying of fur & $0.04(6.31)$ & $0.02(5.38)$ \\
\hline 19 & $\begin{array}{l}\text { Tanning and dressing of leather; manufacture of luggage, } \\
\text { handbags, saddlery, harness and footwear }\end{array}$ & $0.09(5.83)$ & -- \\
\hline 20 & $\begin{array}{l}\text { Manufacture of wood, products of wood and cork, except } \\
\text { furniture; manufacture of articles and straw }\end{array}$ & $0.03(5.78)$ & $0.04(5.52)$ \\
\hline 21 & Manufacture of pulp, paper and paper products & $0.05(5.96)$ & $0.04(5.32)$ \\
\hline 22 & Publishing, printing and reproduction of recorded media & $0.03(5.95)$ & $0.04(5.51)$ \\
\hline 23 & $\begin{array}{l}\text { Manufacture of coke, refined petroleum products and nuclear } \\
\text { fuel }\end{array}$ & 0.07 (6.38) & $0.02(6.61)$ \\
\hline 24 & Chemicals and chemical products & $0.05(6.09)$ & $0.03(5.61)$ \\
\hline 25 & Manufacture of rubber and plastic products & $0.04(5.94)$ & $0.00(5.64)$ \\
\hline 26 & Other non-metallic mineral products & $0.04(5.67)$ & $0.05(5.24)$ \\
\hline 27 & Basic metals & $0.05(6.02)$ & $0.07(5.74)$ \\
\hline 28 & Fabricated metal products, except machinery and equipment & $0.06(5.86)$ & $0.04(5.68)$ \\
\hline 29 & Machinery and equipment n.e.c & 0.05 (5.97) & $0.04(5.62)$ \\
\hline 30 & Manufacture of office machinery and computers & $0.09(6.00)$ & $0.00(6.96)$ \\
\hline 31 & Manufacture of electrical machinery and apparatus n.e.c & $0.05(5.98)$ & $0.07(5.74)$ \\
\hline 32 & $\begin{array}{l}\text { Manufacture of radio, television and communication } \\
\text { equipment and apparatus }\end{array}$ & $0.06(6.11)$ & $0.09(5.82)$ \\
\hline 33 & $\begin{array}{l}\text { Manufacture of medical, precision and optical instruments, } \\
\text { watches and clocks }\end{array}$ & $0.03(5.88)$ & $0.03(5.27)$ \\
\hline 34 & Manufacture of motor vehicles, trailers and semi-trailers & $0.06(6.30)$ & $0.00(5.92)$ \\
\hline 35 & Manufacture of other transport equipment & $0.05(6.43)$ & $0.04(6.18)$ \\
\hline 36 & Manufacture of furniture; manufacturing n.e.c. & $0.03(5.97)$ & $0.00(5.12)$ \\
\hline 37 & Recycling & $-0.01(4.65)$ & -- \\
\hline 45 & Construction & $0.02(9.56)$ & $0.02(8.55)$ \\
\hline 50 & $\begin{array}{l}\text { Sale, maintenance and repair of motor vehicles and } \\
\text { motorcycles; retail sale of automotive fuel }\end{array}$ & $0.03(10.21)$ & $0.01(9.32)$ \\
\hline 51 & $\begin{array}{l}\text { Wholesale trade and commission trade, except of motor } \\
\text { vehicles and motorcycles }\end{array}$ & $0.03(10.27)$ & $0.03(9.57)$ \\
\hline 52 & $\begin{array}{l}\text { Retail trade, except of motor vehicles and motorcycles; repair } \\
\text { of personal and household goods }\end{array}$ & $0.02(10.06)$ & $0.03(8.92)$ \\
\hline 55 & Hotels and restaurants & $0.02(9.01)$ & $0.01(9.01)$ \\
\hline 60 & Land transport; transport via pipelines & $0.00(9.13)$ & $0.00(8.32)$ \\
\hline 61 & Water transport & $0.02(9.78)$ & $0.00(9.45)$ \\
\hline 62 & Air transport & $0.03(11.02)$ & -- \\
\hline 63 & $\begin{array}{l}\text { Supporting and auxiliary transport activities; activities of } \\
\text { travel agencies }\end{array}$ & $0.02(9.81)$ & $0.01(8.63)$ \\
\hline 64 & Post and telecommunications & $0.03(10.02)$ & -- \\
\hline 65 & $\begin{array}{l}\text { Financial intermediation, except insurance and pension } \\
\text { funding }\end{array}$ & $0.03(10.02)$ & -- \\
\hline 67 & Activities auxiliary to financial intermediation & $0.00(9.93)$ & -- \\
\hline 70 & Real estate activities & $0.01(9.56)$ & $0.01(9.18)$ \\
\hline 71 & $\begin{array}{l}\text { Renting of machinery and equipment without operator and of } \\
\text { personal and household goods }\end{array}$ & $0.04(10.23)$ & 0.00 (8.69) \\
\hline 72 & Computer and related activities & $0.02(9.40)$ & $0.01(8.94)$ \\
\hline 73 & Research and development & $0.02(8.99)$ & $0.02(9.31)$ \\
\hline 74 & Other business activities & $0.02(9.99)$ & $0.00(8.71)$ \\
\hline
\end{tabular}

Note: Average TFP in levels are given in brackets. 


\section{References}

Ackerberg, D., K. Caves, and G. Frazer (2005). Structural Identification of Production

Functions. Working Paper, available at http://www.colorado.edu/

Economics/seminars/ackerberg.pdf

Alvarez, R., and R. Lopez (2005). Exporting and Performance: Evidence from

Chilean Plants. Canadian Journal of Economics 38 (4): 1384-1400.

Arnold, J. M., and K. Hussinger (2006). Exports versus FDI in German Manufacturing:

Firm Performance and Participation in International Markets. Discussion Paper 04/06.

Deutsche Bundesbank, Frankfurt am Main.

Bellak, C., and M. Pfaffermayr (2002). Why Foreign-Owned Firms Are Different:

A Conceptual Framework and Empirical Evidence for Austria. In R. Jungnickel

(ed.), Foreign-Owned Firms: Are They Different? Basingstoke: Palgrave.

Bellmann, L., and R Jungnickel (2002). Why Do Foreign-Owned Firms in Germany

Achieve Above-Average Productivity? In R. Jungnickel (ed.), ForeignOwned Firms: Are

They Different? Basingstoke: Palgrave.

Blalock, G., and P. Gertler (2004). Learning from Exporting: Revisited in a Less

Developed Setting. Journal of Development Economics 75 (2): 397-416.

Blomström, M., S. Globerman, and A. Kokko (2001). The Determinants of Host

Country Spillovers from Foreign Direct Investment. In N. Pain (ed.), Inward

Investment, Technological Change and Growth. Basingstoke: Palgrave.

Braconier, H., and K. Ekholm (2002). Locating Foreign Affiliates in Germany:

The Case of Swedish Multinational Enterprises. In R. Jungnickel (ed.), ForeignOwned

Firms: Are They Different? Basingstoke: Palgrave.

Budd, J. W., J. Konings, and M. J. Slaughter (2005). Wages and International Rent

Sharing in Multinational Firms. Review of Economics and Statistics 87 (1): 73-

84.

Castellani, C., and A. Zanfei (2006). Attracting Foreign Investments or Promoting

Domestic Multinationals? Evidence from Productivity Spillovers in Italy. Paper presented at EARIE, Amsterdam.

Conyon, M., S. Girma, S. Thompson, and P. Wright (2004). Do Wages Rise or Fall

Following Merger? Oxford Bulletin of Economics and Statistics 66 (5): 847-862.

Criscuolo, C., and R. Martin (2005). Multinationals, Foreign Ownership and Productivity in

UK Businesses. Working Paper 024. Advanced Institute of Management Research, London. 
Davies, S. W., and B. R. Lyons (1991). Characterising Relative Performance: The Productivity Advantage of Foreign Owned Firms in the UK. Oxford Economic Papers 43 (4): 584-595.

Doms, M. E., and B. J. Jensen (1998). Comparing Wages, Skills, and Productivity between Domestically and Foreign-Owned Manufacturing Establishments in the United States. In R. E. Baldwin, R. E. Lipsey, and J. D. Richardson (eds.), Geography and Ownership as Bases for Economic Accounting. Studies in Income and Wealth 59. Chicago: University of Chicago Press.

Department of Trade and Industry (2006). International Trade and Investment The Economic Rationale for Government Support. Economics Paper 18, available at http://www.dti.gov.uk/files/file32297.pdf

Dunning, J. H. (1988). The Eclectic Paradigm of International Production: A Restatement and Some Possible Extensions. Journal of International Business Studies 19 (1): 1-31.

Federal Ministry of Economics and Technology (2007). Press Release Given by Federal Minister of Economics and Technology, Mr Michael Glos and The Federal Government Commissioner, Mr Wolfgang Tiefensee. Available at http://www.bmvbs.de/en/Federal-Government-Commissione/Economy-andinvestments,2575.985440/Tiefensee-and-Glos-Activities-.htm

Globerman, S., J. C. Ries, and I. Vertinsky (1994). The Economic Performance of Foreign Affiliates in Canada. Canadian Journal of Economics 27 (1): 143-156.

Görg, H., and D. Greenaway (2004). Much Ado about Nothing? Do Domestic Firms Really Benefit from Foreign Direct Investment? World Bank Research Observer 19 (2): 171-197.

Griffith, R. (1999). Using the ARD establishment level data to look at foreign ownership and productivity in the United Kingdom. Economic Journal 109 (June): 416-442.

Griffith, R., and H. Simpson (2004). Characteristics of Foreign-Owned Firms in British Manufacturing. In D. Card, R. Blundell, and R. Freeman (eds.), Seeking a Premier Economy: The Economic Effects of British Economic Reforms, 19802000. Chicago: University of Chicago Press.

Griffith, R., R. Redding, and H. Simpson (2004). Foreign Ownership and Productivity: New Evidence from the Service Sector and the R\&D Lab. Oxford Review of Economic Policy 20 (3): 440-456. 
Griffith, R., R. Harrison, and J. Van Reenen (2006). How Special Is the Special Relationship? Using the Impact of US R\&D Spillovers on UK Firms as a Test of Technology Sourcing. American Economic Review 96 (5): 1859-1875. Halvorsen, R., and R. Palmquist (1980). The Interpretation of Dummy Variables in Semilogarithmic Equations. American Economic Review 70 (3): 474-475. Helpman, E., M. J. Melitz, and S. R. Yeaple (2004). Export versus FDI with Heterogeneous Firms. American Economic Review 94 (1): 300-316.

Howenstine, N. G., and W. J. Zeile (1992). Foreign Direct Investment in the United States: Establishment Data for 1987. Survey of Current Business 72 (10): 44-78.

IMF (International Monetary Fund) (1993). Balance of Payments Manual. Fifth Edition. Washington D.C.: IMF.

Konings, J., and A. Murphy (2006). Do Multinational Enterprises Relocate Employment to Low-Wage Regions? Evidence from European Multinationals.

Review of World Economics/Weltwirtschaftliches Archiv 142 (1): 1-20.

Laafia, I. (2002). Employment in High Tech and Knowledge Intensive Sectors in the EU Continues to Grow in 2001. Eurostat, Statistics in Focus: Science and Technology 9 (4): 1-8.

Levinsohn, J., and A. Petrin (2003). Estimating Production Functions Using Inputs to Control for Unobservables. Review of Economic Studies 70 (2): 317-341.

OECD (Organisation for Economic Cooperation) (1996). Benchmark Definition of Foreign Direct Investment. Third Edition. Paris: OECD.

Olley, S., and A. Pakes (1996). The Dynamics of Productivity in the Telecommunications Equipment Industry. Econometrica 64 (6): 1263-1298.

Oulton, N. (1998a). Investment, Capital and Foreign Ownership in UK Manufacturing.

NIESR Discussion Paper 141. National Institute of Economic and Social

Research, London.

Oulton, N. (1998b). Labour Productivity and Foreign Ownership. NIESR Discussion Paper 143. National Institute of Economic and Social Research, London.

Peri, G., and D. Urban (2006). Catching-up to Foreign Technology? Evidence on the Veblen-Gerschenkron Effect of Foreign Investments. Regional Science and Urban Economics 36 (1): 72-98.

Sinn, H. W. (2000). Germany’s Economic Unification: An Assessment after Ten 
Years. NBER Working Paper 7586. National Bureau of Economic Research, Cambridge, Mass.

Smarzynska Javorcik, B. (2004). Does Foreign Direct Investment Increase the Productivity of Domestic Firms? In Search of Spillovers through Backward Linkages. American Economic Review 94 (3): 605-627.

Wagner, J. (2006). Exports, Foreign Direct Investment, and Productivity: Evidence from German Firm-Level Data. Applied Economics Letters 13 (6): 347-349. Wooldridge, J. (2005). On Estimating Firm-Level Production Functions Using Proxy Variables to Control for Unobservables. Working Paper available at http://www.msu.edu/ ec/faculty/wooldridge/current\%20research/panel8r2.pdf UNCTAD (United Nations Conference on Trade and Development) (2005). World Investment Report 2005. New York and Geneva: United Nations. 